\title{
Effect of increasing levels of raw and extruded narrow-leafed lupin seeds in broiler diet on performance parameters, nutrient digestibility and $A M E_{N}$ value of diet
}

\author{
M. Hejdysz ${ }^{1,3}$, S.A. Kaczmarek', M. Kubiś', D. Jamroz², M. Kasprowicz-Potocka', \\ A. Zaworska ${ }^{1}$ and A. Rutkowski ${ }^{1}$ \\ ${ }_{1}^{1}$ Poznań University of Life Sciences, Department of Animal Nutrition and Feed Management, \\ Wołyńska 33, 60-637 Poznań, Poland \\ ${ }^{2}$ Wrockaw University of Environmental and Life Sciences, Department of Animal Nutrition and Feed Quality, \\ Chełmońskiego 38C, 51-630 Wrocław, Poland
}

KEY WORDS: digestibility, extrusion, Lupinus angustifolius, performance, poultry

Received: 29 August 2017

Revised: 20 November 2017

Accepted: 1 February 2018

${ }^{3}$ Corresponding author:

e-mail: marhej@up.poznan.pl

\begin{abstract}
In the first study conducted to investigate the nutritional value of raw and extruded narrow-leafed lupin (Lupinus angustifolius) seeds cv. Boruta, 60 male Ross 308 chickens of age 16-20 days were used (Experiment 1). In 35-day performance trial (Experiment 2), 960 1-day-old chickens were randomly allotted to 11 treatments and fed diets containing 0, 50, 100, 200, 250 or $300 \mathrm{~g} \cdot \mathrm{kg}^{-1}$ diet of raw or extruded narrow-leafed lupin seeds. In the first experiment, extrusion of narrow-leafed lupin seeds led to the decrease of neutral detergent fibre (NDF) concentration. Seed processing increased fat digestibility and nitrogen retention in chickens but had no effect on ileal digestibility of protein and amino acids. There was a tendency to increase the apparent metabolizable energy corrected to zero $\mathrm{N}$ balance $\left(\mathrm{AME}_{\mathrm{N}}\right.$ ) after lupin extrusion. In the second experiment, the inclusion of increasing levels of raw or extruded seeds into diets quadratically decreased body weight gains (BWGs) of birds, except for broilers fed extruded lupin on days 15-35. The extrusion increased the BWGs of birds in the whole trial period (days 0-35). Increasing levels of raw and extruded narrow-leafed lupin seeds quadratically increased feed conversion ratio during the experiment. So, the extrusion of narrow-leafed lupin seeds had a limited positive effect on the chemical composition of seeds and growth performance of broiler chickens.
\end{abstract}

\section{Introduction}

The growing interest in cultivation and the introduction of legume seeds into animal and poultry diets has been observed in recent years. It was shown that biologically active legume proteins, rich in lysine, have antioxidant properties (Nalle et al., 2011; Smulikowska et al., 2013; Kaczmarek et al. 2014; Hejdysz et al. 2015, 2016a,b; Rutkowski et al., 2015, 2017). Antioxidants (such as selenium and vitamin $\mathrm{E})$ and microelements $(\mathrm{Zn}, \mathrm{Cu}, \mathrm{Mn})$ supporting the immune system are among other beneficial components of legume seeds (Wasilewko and Buraczewska, 1999; Lampart-Szczapa and Łoza, 2007).

Antinutritional factors present in seeds such as protease inhibitors, alkaloids, $\alpha$-galactosides and tannins limit inclusion levels of legume seeds in diets, especially foryoung, growing animals (Smulikowska et al., 1999; Laudadio and Tufarelli, 2011b). 
However, optimum inclusion levels of some of these substances are associated with health-promoting activities (Jamroz and Kubizna, 2008).

Different preparation methods of legume seeds, such as dehulling that decreases the content of dietary fibre and phenolic compounds or thermal and baro-thermal processing that reduces the activity of thermal-sensitive proteases and inhibitors, can improve the nutritional value of seeds (Leontowicz et al., 2001; Lampart-Szczapa et al., 2007; Laudadio and Tufarelli, 2011a).

In the previous studies in which yellow lupin seeds were used (raw or extruded) in broiler diets in a share of $5-30 \%$, it was found that the extrusion improved fat digestibility of seeds and nitrogen retention in chickens, and enhanced the apparent metabolizable energy corrected to zero $\mathrm{N}$ balance $\left(\mathrm{AME}_{\mathrm{N}}\right)$ value of seeds (Rutkowski et al., 2015). However, the inclusion of $25 \%$ or $30 \%$ of either raw or extruded yellow lupin seeds into diets significantly decreased the performance indices of broiler chickens. Using $10 \%$ or $20 \%$ of extruded seeds positively affected growth and feed conversion ratio of birds in comparison to those fed diets with raw seeds (Rutkowski et al., 2015).

Published data on the usefulness of narrowleafed lupin (Lupinus angustifolius) seeds, as a replacement for soyabean meal, in broiler diets are limited and contradictory (Farrell et al., 1999; Rubio et al., 2003), with some studies showing lowered performance and others reporting performance similar to control diets at inclusion levels of over $200 \mathrm{~g} \cdot \mathrm{kg}^{-1}$. The positive effect of extrusion on broiler chicken performance was confirmed for yellow lupin seeds. There is no comparative information on the influence of extrusion on the nutritive value of narrow-leafed lupin and broiler chickens performance. Therefore, the objective of this study was to evaluate the effect of increasing levels of raw and extruded narrow-leafed lupin seeds on nutrient utilization, $\mathrm{AME}_{\mathrm{N}}$ value and growth performance of broiler chickens.

\section{Material and methods}

\section{Lupin seeds processing}

Raw or extruded narrow-leafed lupin seeds (Lupinus angustifolius) cv. Boruta harvested in 2014 were used. Seeds were obtained from the Plant Breeding Stations in Wiatrowo (Poland). A portion of lupin seeds was extruded using a KMZ 2 extruder (Russia) $\left(500 \mathrm{~kg} \cdot \mathrm{h}^{-1}\right)$. The extrusion process was carried out under the following conditions: moisture $22 \%$, time $10 \mathrm{~s}$, temperature $135 \pm 10{ }^{\circ} \mathrm{C}$ and pressure $30 \mathrm{~kg} \cdot \mathrm{cm}^{-2}$. The extruded seeds were allowed to cool to room temperature, reground to pass through a $3.18 \mathrm{~mm}$ sieve and stored at $4{ }^{\circ} \mathrm{C}$.

\section{Nutrient digestibility and growth performance trials}

Experiment 1. The experiment was carried out on 60 16-day-old Ross 308 male chickens, reared from birth in cages and fed basal diets (Table 1). At 16 day of age, birds were randomly allotted to individual cages and assigned to three dietary treatments, 20 replicates in each. Broilers from control group were fed a basal diet, whereas broilers in experimental groups - two experimental diets containing $80 \%$ of the basal diet and $20 \%$ of raw or extruded lupin. For the determination of total or ileal digestibility, $3 \mathrm{~g} \cdot \mathrm{kg}^{-1}$ of $\mathrm{TiO}_{2}$ was added to diets as an indigestible marker. All diets were offered ad libitum in a mash form. During the 5 days of accommodation, birds were also fed experimental diets. On days 19 and 20 , the excreta of chickens were individually collected twice a day and immediately frozen for further analyses $(\mathrm{n}=20$ per treatment). On day 21, all chickens from each group were sacrificed by cervical dislocation and their ileums were removed. Digesta was flushed from the terminal ileum $(15 \mathrm{~cm}$, near the ileocecal junction) and pooled (two birds per sample) to provide adequate quantities for chemical analyses.

\begin{tabular}{lc}
\multicolumn{2}{l}{ Table 1. Composition of basal diet, $\mathrm{g} \cdot \mathrm{kg}^{-1}$ (Experiment 1) } \\
\hline Components & $\mathrm{g} \cdot \mathrm{kg}^{-1}$ \\
\hline Maize & 600.0 \\
Soyabean meal (CP 44\%) & 292.6 \\
Soyabean oil & 41.6 \\
Fish meal & 29.4 \\
Monocalcium phosphate & 10.3 \\
Chalk (<2 mm) & 5.1 \\
Premix $x^{1}$, broiler & 10.0 \\
NaCl & 2.9 \\
$\mathrm{NaHCO}_{3}$ & 0.1 \\
DL-methionine & 2.7 \\
L-lysine & 1.7 \\
L-threonine & 0.6 \\
TiO & \\
Analysed & 3.0 \\
$\quad$ metabolizable energy, $\mathrm{MJ} \cdot \mathrm{kg}^{-1}$ & 12.85 \\
$\quad$ crude protein & 218.0 \\
$\quad$ ether extract & 71.9 \\
\hline
\end{tabular}

${ }^{1}$ provided per $\mathrm{kg}$ diet: IU: vit. A 11250, cholecalciferol 2500; mg: vit. $E 80$, menadione 2.50 , vit. $B_{12} 0.02$, folic acid 1.17 , choline 379 , D-pantothenic acid 12.5, riboflavin 7.0, niacin 41.67, thiamine 2.17, D-biotin 0.18 , pyridoxine 4.0 , ethoxyquin $0.09, \mathrm{Mn} 73$, Zn 55 , Fe 45, Cu 20, I 0.62, Se 0.3, salinomycin 60 
Experiment 2. In total, 960 1-day-old male Ross 308 chickens (initial individual weight: $42 \pm 3 \mathrm{~g}$ ) were randomly assigned to 11 dietary treatments $(10$ cages per replicate, 8 birds per treatment). In the experiment, in a control group 20 received replications were included. Birds were obtained from a commercial hatchery (DanHach Poland, Wolsztyn, Poland). Chickens were kept in cages $\left(0.5 \mathrm{~m}^{2}, 8\right.$ birds in each) on straw litter. The environmental conditions were typical for broiler rearing; the lighting program in the first 7 days was $24 \mathrm{~h} \cdot \mathrm{d}^{-1}$, and then, $18 \mathrm{~h}$ light: $6 \mathrm{~h}$ darkness. The temperature was maintained at $32{ }^{\circ} \mathrm{C}$ during the first week and was gradually decreased to $\sim 23^{\circ} \mathrm{C}$ by the end of the third week.

Diets and drinking water were provided $a d$ libitum. The chickens were fed starter (0-14 days of age) and grower diets (15-35 days) in a mash form.
Diets containing $21-22 \%$ of crude protein $(\mathrm{CP})$ and 12.6-13 $\mathrm{MJ} \cdot \mathrm{kg}^{-1}$ of metabolizable energy were used. Diets contained narrow-leafed lupin seeds (cv. Boruta) $\left(50,100,200,250\right.$ and $300 \mathrm{~g} \cdot \mathrm{kg}^{-1}$ diet) instead of soyabean meal (Tables 2 and 3). In treatments R50, R100, R200, R250 and R300, diets contained raw seeds, whereas in treatments E50, E100, E200, E250 and E300, analogous quantities of extruded lupin seeds were used. The control diet (C) did not contain lupin seeds.

Body weight and feed intake (FI) were monitored after 14 days and at the end of the experiment, with the cage serving as the experimental unit. Before weighing, the birds were fasted for $4 \mathrm{~h}$. Mean weight gain, FI and feed conversion ratio (FCR) were used to determine the growth performance following any necessary corrections for mortality. Mortality in the experiments was very low and averaged $1.1 \%$.

Table 2. Ingredient composition and nutrient content of starter diets containing different levels of narrow-leafed lupin meal in raw (R) or extruded form (E), $\mathrm{g} \cdot \mathrm{kg}^{-1}$ (Experiment 2)

\begin{tabular}{|c|c|c|c|c|c|c|c|c|c|c|c|}
\hline \multirow{2}{*}{ Component } & \multicolumn{11}{|l|}{ Starter } \\
\hline & Control & R50 & R100 & R200 & R250 & R300 & $\mathrm{E} 50$ & E100 & E200 & E250 & E300 \\
\hline Maize & 468.0 & 448.4 & 422.6 & 368.9 & 359.1 & 326.7 & 448.4 & 422.6 & 368.9 & 359.1 & 326.7 \\
\hline Raw narrow-leafed lupin & - & 50.0 & 100.0 & 200.0 & 250.0 & 300.0 & 50.0 & 100.0 & 200.0 & 250.0 & 300.0 \\
\hline Extruded narrow-leafed lupin & - & - & - & - & - & - & - & - & - & - & - \\
\hline Soya oil & 56.0 & 60.0 & 66.0 & 81.0 & 82.0 & 86.0 & 60.0 & 66.0 & 81.0 & 82.0 & 86.0 \\
\hline Soyabean meal (CP 44\%) & 306.5 & 272.0 & 242.0 & 180.0 & 138.0 & 115.8 & 272.0 & 242.0 & 180.0 & 138.0 & 115.8 \\
\hline Rapeseed meal (CP 34.9\%) & 80.0 & 80.0 & 80.0 & 80.0 & 80.0 & 80.0 & 80.0 & 80.0 & 80.0 & 80.0 & 80.0 \\
\hline DDGS (CP 36\%) & 50.0 & 50.0 & 50.0 & 50.0 & 50.0 & 50.0 & 50.0 & 50.0 & 50.0 & 50.0 & 50.0 \\
\hline Limestone (<2 mm) & 4.4 & 4.4 & 4.3 & 4.4 & 4.6 & 4.5 & 4.4 & 4.3 & 4.4 & 4.6 & 4.5 \\
\hline Monocalcium phosphate & 13.8 & 13.5 & 13.2 & 12.8 & 13.0 & 14.0 & 13.5 & 13.2 & 12.8 & 13.0 & 14.0 \\
\hline Premix ${ }^{1}$, broiler & 10.0 & 10.0 & 10.0 & 10.0 & 10.0 & 10.0 & 10.0 & 10.0 & 10.0 & 10.0 & 10.0 \\
\hline $\mathrm{NaHCO}_{3}$ & 3.6 & 4.0 & 2.9 & 3.6 & 3.6 & 3.6 & 4.0 & 2.9 & 3.6 & 3.6 & 3.6 \\
\hline $\mathrm{NaCl}$ & 1.0 & 0.6 & 1.1 & 1.0 & 1.0 & 1.0 & 0.6 & 1.1 & 1.0 & 1.0 & 1.0 \\
\hline L-lysine $\mathrm{HCl}(98 \%)$ & 3.7 & 3.9 & 3.9 & 4.4 & 4.4 & 4.0 & 3.9 & 3.9 & 4.4 & 4.4 & 4.0 \\
\hline DL-methionine & 1.5 & 1.7 & 1.7 & 2.0 & 2.1 & 2.2 & 1.7 & 1.7 & 2.0 & 2.1 & 2.2 \\
\hline L-threonine & 0.9 & 0.9 & 1.1 & 0.9 & 1.0 & 0.9 & 0.9 & 1.1 & 0.9 & 1.0 & 0.9 \\
\hline L-valine & 0.5 & 0.5 & 1.0 & 0.7 & 0.9 & 1.0 & 0.5 & 1.0 & 0.7 & 0.9 & 1.0 \\
\hline L-tryptophan & 0.1 & 0.1 & 0.2 & 0.3 & 0.3 & 0.3 & 0.1 & 0.2 & 0.3 & 0.3 & 0.3 \\
\hline \multicolumn{12}{|l|}{ Calculated } \\
\hline metabolizable energy, $\mathrm{MJ} \cdot \mathrm{kg}^{-1}$ & 12.14 & 12.11 & 12.11 & 12.12 & 12.14 & 12.11 & 12.11 & 12.11 & 12.12 & 12.14 & 12.11 \\
\hline lysine (digest.) & 12.8 & 12.8 & 12.8 & 12.8 & 12.8 & 12.8 & 12.8 & 12.8 & 12.8 & 12.8 & 12.8 \\
\hline methionine (digest.) & 5.1 & 5.1 & 5.1 & 5.1 & 5.1 & 5.1 & 5.1 & 5.1 & 5.1 & 5.1 & 5.1 \\
\hline threonine (digest.) & 8.6 & 8.6 & 8.6 & 8.6 & 8.6 & 8.6 & 8.6 & 8.6 & 8.6 & 8.6 & 8.6 \\
\hline calcium & 9.6 & 9.6 & 9.6 & 9.6 & 9.6 & 9.6 & 9.6 & 9.6 & 9.6 & 9.6 & 9.6 \\
\hline sodium & 2.0 & 2.0 & 2.0 & 2.0 & 2.0 & 2.0 & 2.0 & 2.0 & 2.0 & 2.0 & 2.0 \\
\hline chlorine & 2.0 & 2.0 & 2.0 & 2.0 & 2.0 & 2.0 & 2.0 & 2.0 & 2.0 & 2.0 & 2.0 \\
\hline \multicolumn{12}{|l|}{ Analysed } \\
\hline crude protein, $\mathrm{g} \cdot \mathrm{kg}^{-1}$ & 218.0 & 219.0 & 220.0 & 218.0 & 221.0 & 220.0 & 220.0 & 221.0 & 219.0 & 220.0 & 221.0 \\
\hline
\end{tabular}

DDGS - dried distillers with solubles; ${ }^{1}$ provided per $\mathrm{kg}$ diet: IU: vit. A 11250, cholecalciferol 2500; mg: vit. E 80, menadione 2.50, cyanocobalamine 0.02 , folic acid 1.17 , choline 379 , D-pantothenic acid 12.5 , riboflavin 7.0 , niacin 41.67 , thiamine 2.17 , D-biotin 0.18 , pyridoxine 4.0, ethoxyquin $0.09, \mathrm{Mn} 73, \mathrm{Zn} 55, \mathrm{Fe} 45, \mathrm{Cu} 20, \mathrm{I} 0.62$, Se 0.3 , salinomycin 60 
Table 3. Ingredient composition and nutrient content of grower diets containing different levels of narrow-leafed lupin meal in raw (R) or extruded form $(E), \mathrm{g} \cdot \mathrm{kg}^{-1}$ (Experiment 2)

\begin{tabular}{|c|c|c|c|c|c|c|c|c|c|c|c|}
\hline \multirow{2}{*}{ Component } & \multicolumn{11}{|l|}{ Grower } \\
\hline & Control & $\mathrm{R} 50$ & R100 & R200 & $\mathrm{R} 250$ & R300 & E50 & E100 & E200 & E250 & E300 \\
\hline Maize & 500.0 & 473.3 & 451.9 & 400.0 & 385.1 & 357.1 & 473.3 & 451.9 & 400.0 & 385.1 & 357.1 \\
\hline Raw narrow-leafed lupin & - & - & - & - & - & - & - & - & - & - & - \\
\hline Extruded narrow-leafed lupin & - & 50.0 & 100.0 & 200.0 & 250.0 & 300.0 & 50.0 & 100.0 & 200.0 & 250.0 & 300.0 \\
\hline soya oil & 79.0 & 85.0 & 89.0 & 102.0 & 106.0 & 107.0 & 85.0 & 89.0 & 102.0 & 106.0 & 107.0 \\
\hline soyabean meal (CP 44\%) & 253.2 & 224.1 & 192.0 & 130.0 & 90.0 & 65.8 & 224.1 & 192.0 & 130.0 & 90.0 & 65.8 \\
\hline rapeseed meal (CP 34.9\%) & 80.0 & 80.0 & 80.0 & 80.0 & 80.0 & 80.0 & 80.0 & 80.0 & 80.0 & 80.0 & 80.0 \\
\hline DDGS (CP 36\%) & 50.0 & 50.0 & 50.0 & 50.0 & 50.0 & 50.0 & 50.0 & 50.0 & 50.0 & 50.0 & 50.0 \\
\hline limestone (<2 mm) & 3.3 & 3.1 & 3.1 & 3.1 & 3.2 & 3.3 & 3.1 & 3.1 & 3.1 & 3.2 & 3.3 \\
\hline monocalcium phosphate & 14.9 & 14.6 & 14.4 & 14.0 & 14.5 & 15.0 & 14.6 & 14.4 & 14.0 & 14.5 & 15.0 \\
\hline Premix ${ }^{1}$, broiler & 10.0 & 10.0 & 10.0 & 10.0 & 10.0 & 10.0 & 10.0 & 10.0 & 10.0 & 10.0 & 10.0 \\
\hline $\mathrm{NaHCO}_{3}$ & 3.6 & 4.0 & 2.9 & 3.6 & 3.6 & 3.6 & 4.0 & 2.9 & 3.6 & 3.6 & 3.6 \\
\hline $\mathrm{NaCl}$ & 1.0 & 0.7 & 1.1 & 1.0 & 1.0 & 1.0 & 0.7 & 1.1 & 1.0 & 1.0 & 1.0 \\
\hline L-lysine $\mathrm{HCl}(98 \%)$ & 3.0 & 3.1 & 3.2 & 3.5 & 3.5 & 3.9 & 3.1 & 3.2 & 3.5 & 3.5 & 3.9 \\
\hline DL-methionine & 1.2 & 1.3 & 1.4 & 1.6 & 1.8 & 1.9 & 1.3 & 1.4 & 1.6 & 1.8 & 1.9 \\
\hline L-threonine & 0.6 & 0.6 & 0.6 & 0.6 & 0.6 & 0.6 & 0.6 & 0.6 & 0.6 & 0.6 & 0.6 \\
\hline L-valine & 0.1 & 0.1 & 0.2 & 0.3 & 0.4 & 0.5 & 0.1 & 0.2 & 0.3 & 0.4 & 0.5 \\
\hline L-tryptophan & 0.1 & 0.1 & 0.2 & 0.3 & 0.3 & 0.3 & 0.1 & 0.2 & 0.3 & 0.3 & 0.3 \\
\hline \multicolumn{12}{|l|}{ Calculated } \\
\hline metabolizable energy, $\mathrm{MJ} \cdot \mathrm{kg}^{-1}$ & 12.76 & 12.69 & 12.75 & 12.71 & 12.78 & 12.74 & 12.69 & 12.75 & 12.71 & 12.78 & 12.74 \\
\hline lysine (digest.) & 11.5 & 11.5 & 11.5 & 11.5 & 11.5 & 11.5 & 11.5 & 11.5 & 11.5 & 11.5 & 11.5 \\
\hline methionine (digest.) & 4.7 & 4.7 & 4.7 & 4.7 & 4.7 & 4.7 & 4.7 & 4.7 & 4.7 & 4.7 & 4.7 \\
\hline threonine (digest.) & 7.7 & 7.7 & 7.7 & 7.7 & 7.7 & 7.7 & 7.7 & 7.7 & 7.7 & 7.7 & 7.7 \\
\hline calcium & 8.7 & 8.7 & 8.7 & 8.7 & 8.7 & 8.7 & 8.7 & 8.7 & 8.7 & 8.7 & 8.7 \\
\hline sodium & 2.0 & 2.0 & 2.0 & 2.0 & 2.0 & 2.0 & 2.0 & 2.0 & 2.0 & 2.0 & 2.0 \\
\hline chlorine & 2.0 & 2.0 & 2.0 & 2.0 & 2.0 & 2.0 & 2.0 & 2.0 & 2.0 & 2.0 & 2.0 \\
\hline \multicolumn{12}{|l|}{ Analysed } \\
\hline crude protein, $\mathrm{g} \cdot \mathrm{kg}^{-1}$ & 210.0 & 209.0 & 211.0 & 213.0 & 212.0 & 209.0 & 212.0 & 213.0 & 209.0 & 212.0 & 209.0 \\
\hline
\end{tabular}

DDGS - dried distillers with solubles; ${ }^{1}$ provided per kg diet: IU: vit. A 11250, cholecalciferol 2500; $\mathrm{mg}$ : vit. E 80, menadione 2.50, cyanocobalamine 0.02 , folic acid 1.17, choline 379 , D-pantothenic acid 12.5 , riboflavin 7.0, niacin 41.67, thiamin 2.17, D-biotin 0.18, pyridoxine 4.0, ethoxyquin 0.09 , Mn 73, Zn 55, Fe 45, Cu 20, I 0.62, Se 0.3, salinomycin 60

\section{Chemical analyses}

Representative samples of both raw and extruded lupin seeds and experimental diets were ground to pass through a $0.5 \mathrm{~mm}$ sieve. The AOAC International (2007) methods 934.01, 976.05, 920.39, 942.05 and 973.18 were used for dry matter (DM), $\mathrm{CP}$, ether extract (EE), acid detergent fibre (ADF) and neutral detergent fibre (NDF) analyses, respectively. All samples were analysed in duplicate.

The amino acid (AA) content was determined using an AAA-400 Automatic Amino Acid Analyzer (Ingos, Prague, Czech Republic) with ninhydrin for post-column derivatization. The samples were hydrolysed with $6 \mathrm{~N} \mathrm{HCl}$ for $24 \mathrm{~h}$ at $110^{\circ} \mathrm{C}$ (procedure 994.12; AOAC International, 2007). Gross energy (GE) was determined using an adiabatic bomb calorimeter (KL 12Mn; Precyzja-Bit PPHU, Bydgoszcz, Poland) standardized with benzoic acid. Titanium dioxide was determined according to Short et al. (1996), with samples prepared according to the procedure of Myers et al. (2004).

Raffinose family oligosaccharides were analysed by gas-liquid chromatography as described by Zalewski et al. (2001). Phytate phosphorus was determined using the procedure of Haug and Lantzsch (1983). The water extract viscosity (WEV) of lupin seeds was measured in vitro. Prior to the determination of WEV, lupin samples were ground in a mill using a $0.5 \mathrm{~mm}$ sieve. One gram of sample was mixed with $5 \mathrm{ml}$ of distilled water for $1 \mathrm{~h}$ at $40{ }^{\circ} \mathrm{C}$. The samples were centrifuged at $10000 \mathrm{~g}$ for $10 \mathrm{~min}$ at $4{ }^{\circ} \mathrm{C}$, the supernatant was withdrawn, and viscosity was determined in a Brookfield Digital DV-II+ cone/plate viscometer (Brookfield Engineering Laboratories Inc., Stoughton, MA, USA) maintained at $40{ }^{\circ} \mathrm{C}$ at a shear rate of $12 \mathrm{~s}^{-1}$. The WEV units are $\mathrm{mPas} \cdot \mathrm{s}=\mathrm{cP}=1 \times 100$ dyne $\cdot \mathrm{s} \cdot \mathrm{cm}^{-2}$. 
The energy values of diets were calculated based on the European Tables of Energy Values of Feeds for Poultry (World's Poultry Science Association, 1989) and Polish Poultry Feeding Standards (Smulikowska and Rutkowski, 2005).

\section{Calculations of nutrient digestibility}

Using $\mathrm{CP}$ as an example, the following equation was used for the calculation of digestibility (apparent ileal digestibility and apparent total tract digestibility), $\mathrm{N}$ retention and dry matter (DM) retention as well as $\mathrm{AME}_{\mathrm{N}}$ of various dietary components of the basal and experimental diets:

$$
\mathrm{DC}=\left\{1-\left[\left(\mathrm{TiO}_{2\left[\mathrm{~g} \cdot \mathrm{kg}^{-1} \text { diet }\right]} / \mathrm{TiO}_{2\left[\mathrm{~g} \cdot \mathrm{kg}^{-1} \mathrm{DIG} \text { or EX }\right]}\right)\right.\right.
$$$$
\left.\left.\times\left(\mathrm{CP}_{\left[\mathrm{g} \cdot \mathrm{kg}^{-1} \mathrm{DI}\right. \text { or EX] }} / \mathrm{CP}_{\left[\mathrm{g} \cdot \mathrm{kg}^{-1} \text { diet }\right]}\right)\right]\right\} \times 100 \%
$$

$\mathrm{AME}_{\mathrm{N}\left[\mathrm{kcal} \cdot \mathrm{kg}^{-1]}\right]}=\left[\mathrm{GE}_{\left[\mathrm{kcal} \cdot \mathrm{kg}^{-1} \text { of EX] }\right.} \times\left(\mathrm{TiO}_{2\left[\mathrm{~g} \cdot \mathrm{kg}^{-1} \text { diet }\right]} /\right.\right.$ $\left.\left.\mathrm{TiO}_{2\left[\mathrm{~g} \cdot \mathrm{kg}^{-1} \mathrm{EX}\right]}\right)\right]-34.4 \times\left[\left(\mathrm{N}_{\left[\mathrm{g} \cdot \mathrm{kg}^{-1} \mathrm{EX}\right]}-\left(\mathrm{TiO}_{2\left[\mathrm{~g} \cdot \mathrm{kg}^{-1} \operatorname{diet}\right]} /\right.\right.\right.$

$$
\left.\mathrm{TiO}_{2\left[\mathrm{~g} \cdot \mathrm{kg}^{-1} \mathrm{EX}\right]}\right]
$$

where: DC - digestibility coefficient, DIG - digesta, EX - excreta, GE - gross energy, $\mathrm{N}$ - nitrogen and 34.4 - energy equivalent of uric acid nitrogen (Hill and Anderson, 1958).

$\mathrm{AME}_{\mathrm{N}}$ of all experimental diets was calculated using the previous equations and was corrected to zero nitrogen balance using $34.4 \mathrm{~kJ} \cdot \mathrm{g}^{-1} \mathrm{~N}$ retained (Hill and Anderson, 1958).

The following equation was used to calculate the digestibility coefficients of various dietary components and the $\mathrm{AME}_{\mathrm{N}}$ level of lupin seeds:

$$
\begin{aligned}
& \mathrm{DC}=\left(\mathrm{DC}_{[\mathrm{CP} \text { pea diet }]} \times \mathrm{C}_{\left[\mathrm{g} \cdot \mathrm{kg}^{-1} \mathrm{CP} \text { lupin diet }\right]}-\mathrm{D}_{[\mathrm{CP} \text { basal diet }]}\right. \\
&\left.\times \mathrm{C}_{\left[\mathrm{g} \cdot \mathrm{kg}^{-1} \mathrm{CP} \text { basal diet }\right]} \times 0.20\right) /\left(\mathrm{C}_{[\mathrm{g}} \cdot \mathrm{kg}^{-1} \mathrm{CP} \text { lupin diet }\right] \\
&-\left.-\mathrm{C}_{\left[\mathrm{g} \cdot \mathrm{kg}^{-1} \mathrm{CP} \text { basal diet }\right]} \times 0.20\right) \times 100 \%
\end{aligned}
$$

$\mathrm{AME}_{\mathrm{N}\left[\mathrm{kcal} \cdot \mathrm{kg}^{-1]}\right.}=\left(\mathrm{AME}_{\mathrm{N}\left[\mathrm{kcal} \cdot \mathrm{kg}^{-1} \text { lupin diet }\right]}-\left(\mathrm{AME}_{\mathrm{N}\left[\mathrm{kcal} \cdot \mathrm{kg}^{-1}\right.}\right.\right.$

$$
\text { basal diet] } \times 0.8) / 0.2)
$$

where: DC - digestibility coefficient of $\mathrm{CP}$ in narrow-leafed lupin seeds; $\mathrm{DC}_{[\mathrm{CP} \text { lupin diet] }}-$ digestibility coefficient of $\mathrm{CP}$ in narrow-leafed lupin diet; $\mathrm{C}_{\left[\mathrm{g} \cdot \mathrm{kg}^{-1} \mathrm{CP} \text { lupin diet] }\right.}-$ concentration of $\mathrm{CP}$ in narrowleafed lupin diet; 0.20 - amount of investigated narrow-leafed lupin in narrow-leafed lupin diet; $\mathrm{D}_{\text {[CP basal diet] }}$ - digestibility coefficient of CP in basal diet; $\mathrm{C}_{\left[\mathrm{g} \cdot \mathrm{kg}^{-1} \mathrm{CP} \text { basal diet] }\right.}-$ concentration of $\mathrm{CP}$ in

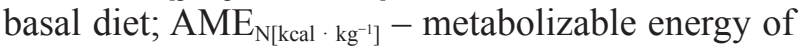
narrow-leafed lupin seeds; $\mathrm{AME}_{\mathrm{N}\left[\mathrm{kcal} \cdot \mathrm{kg}^{-1} \text { lupin diet] }\right.}-$ metabolizable energy of narrow-leafed lupin diet; $\mathrm{AME}_{\mathrm{N}\left[\mathrm{kcal} \cdot \mathrm{kg}^{-1} \text { basal diet] }\right.}$ - metabolizable energy of basal diet; and 0.80 - amount of basal diet in narrowleafed lupin diet.

\section{Statistical analysis}

Experiment 1. All data were earlier explored to discard any possible outliers. Statistical analyses were performed using procedures of $\mathrm{SAS}^{\circledR}$ v. 9.1 package (SAS Institute Inc., Cary, NC, USA) (distribution analyses; outliers were defined as observations that were in the distance bigger than 3 times standard deviation). The obtained results were subjected to Student t-test analysis, at the level of $P<0.05$.

Experiment 2. Statistical calculations were conducted using the $\mathrm{SAS}^{\circledR}$ v. 9.1 package (SAS Institute Inc., Cary, NC, USA). Both the mean values and the standard error of the mean were calculated for all traits. Differences among treatments and experimental factors were determined by using the two-way linear model of analysis of variance:

$$
Y_{i j k}=\alpha_{j}+\beta_{k}+(\alpha \beta)_{j k}+e_{i j k}
$$

where: $Y_{i j k}$ - value of analysed trait; $\alpha_{j}$ - constant effect of $i^{\text {th }}$ lupin seed; $\beta_{k}$ - constant effect of $j^{\text {th }}$ extrusion; $(\alpha \beta)_{j k}$-interaction between $\alpha$ and $\beta$; and $e_{i j k}-$ effect of experimental error.

Orthogonal contrasts were used to establish the difference between treatments. The used contrasts were control treatment vs other five dietary treatments $(50,100,200,250$ and $300 \mathrm{~g}$ of lupin seeds per $\mathrm{kg}$ of feed) as well as the contrast for linear (L) and quadratic (Q) effects. All data are presented as means with pooled standard error of the mean.

\section{Results}

Experiment 1. The extrusion of narrow-leafed lupin seeds led to the decrease in NDF content by $49 \mathrm{~g} \cdot \mathrm{kg}^{-1} \mathrm{DM}$ (Table 4). The GE, crude fat, crude ash, CP and AA contents were similar in both raw and extruded seeds. The contents of alkaloids and oligosaccharides were not affected by seed processing (Table 4).

The extrusion of lupin did not significantly affect DM retention, but there was a tendency to improve DM retention $(P=0.088)$. It increased the apparent total tract digestibility of crude fat $(P<0.05)$ from 73.1 to $86.5 \%$ as well as nitrogen retention from 45.7 to $55.5 \%$ in comparison to raw seeds (Table 5). Seed extrusion resulted in a tendency to enhance the apparent $\mathrm{AME}_{\mathrm{N}}$ value of narrow-leafed lupin by about $0.5 \mathrm{MJ} \cdot \mathrm{kg}^{-1}$ $(P=0.075)$.

The dietary inclusion of extruded lupin seeds did not significantly affect the ileal digestibility of CP (Table 5) but extruded lupin seeds were characterized by lower digestibility coefficients $(P<0.01)$ for methionine and proline.

Experiment 2. There was observed the significant effect of the level of narrow-leafed lupin seed 
Table 4. Chemical composition of narrow-leafed lupin seeds (cv. Boruta), in dry matter basis

\begin{tabular}{|c|c|c|}
\hline \multirow{2}{*}{ Indices } & \multicolumn{2}{|c|}{ Lupin seeds } \\
\hline & raw & extruded \\
\hline Dry matter, $\mathrm{g} \cdot \mathrm{kg}^{-1}$ & 886.2 & 889.5 \\
\hline Crude ash & 37.8 & 38.1 \\
\hline Crude protein & 385.8 & 389.3 \\
\hline ADF & 214.3 & 219.7 \\
\hline NDF & 259.2 & 210.5 \\
\hline Gross Energy, $\mathrm{MJ} \cdot \mathrm{kg}^{-1}$ & 20.73 & 20.78 \\
\hline WEV, cP & 1.61 & 1.68 \\
\hline \multicolumn{3}{|l|}{ Amino acids, $\%$ protein } \\
\hline Asp & 8.91 & 8.92 \\
\hline Thr & 3.15 & 3.12 \\
\hline Ser & 4.11 & 4.14 \\
\hline Glut & 23.77 & 23.81 \\
\hline Pro & 6.52 & 6.54 \\
\hline Cys & 1.11 & 1.14 \\
\hline Met & 0.47 & 0.49 \\
\hline Gly & 4.01 & 4.03 \\
\hline Ala & 3.33 & 3.37 \\
\hline Val & 3.72 & 3.70 \\
\hline Iso & 3.68 & 3.62 \\
\hline Leu & 6.64 & 6.66 \\
\hline Tyr & 3.07 & 3.08 \\
\hline Phe & 3.46 & 3.50 \\
\hline His & 2.91 & 2.93 \\
\hline Lys & 4.49 & 4.53 \\
\hline $\operatorname{Arg}$ & 11.65 & 11.67 \\
\hline \multicolumn{3}{|l|}{ Antinutrients } \\
\hline total alkaloids, $\mathrm{mg} \cdot \mathrm{kg}^{-1}$ & 44.0 & 43.0 \\
\hline angustifoline, $\%$ of total alkaloids & 12.5 & 12.5 \\
\hline izolupaninine, $\%$ of total alkaloids & 4.6 & 4.6 \\
\hline lupanine, $\%$ of total alkaloids & 56.2 & 56.1 \\
\hline $130 \mathrm{H}$ lupanine, $\%$ of total alkaloids & 26.7 & 26.8 \\
\hline oligosaccharides, $\mathrm{g} \cdot \mathrm{kg}^{-1}$ & 87.7 & 88.0 \\
\hline rafinose, $\mathrm{g} \cdot \mathrm{kg}^{-1}$ & 12.0 & 11.8 \\
\hline stachyose, $\mathrm{g} \cdot \mathrm{kg}^{-1}$ & 56.1 & 56.3 \\
\hline verbascose, $\mathrm{g} \cdot \mathrm{kg}^{-1}$ & 19.6 & 19.9 \\
\hline total $P, \mathrm{~g} \cdot \mathrm{kg}^{-1}$ & 7.23 & 7.22 \\
\hline phytate $P, g \cdot \mathrm{kg}^{-1}$ & 4.42 & 4.21 \\
\hline non-phytate $\mathrm{P}, \mathrm{g} \cdot \mathrm{kg}^{-1}$ & 2.81 & 3.01 \\
\hline
\end{tabular}

NDF - neutral detergent fibre, ADF - acid detergent fibre, WEV - water extract viscosity

in all three examined periods (days 0-14, 15-35 and $0-35$ ). Increasing level of raw narrow-leafed lupin in the diet for broiler chickens decreased quadratically the body weight gain (BWG) during all studied experimental periods (Table 6). In the case of extruded seeds, the decrease of BWG was not confirmed for period from days 15 to 35 of the experiment. There was no effect of extrusion on BWG from days 0 to 14 as well as from
Table 5. Coefficients of total tract apparent digestibility of fat, dry matter and nitrogen retention, $\mathrm{AME}_{\mathrm{N}}$ as well as apparent ileal nutrient digestibility of narrow-leafed lupin seeds cv. Boruta in chickens (Experiment 1)

\begin{tabular}{|c|c|c|c|c|}
\hline \multirow{2}{*}{ Indices } & \multicolumn{2}{|c|}{ Lupin seeds } & \multirow{2}{*}{ SEM } & \multirow{2}{*}{ Significance } \\
\hline & raw & extruded & & \\
\hline Dry matter retention, $\%$ & 59.1 & 62.4 & 1.01 & 0.088 \\
\hline Nitrogen retention, $\%$ & 45.7 & 55.5 & 2.11 & 0.048 \\
\hline $\begin{array}{l}\text { Apparent total tract crude fat } \\
\text { digestibility, } \%\end{array}$ & 73.1 & 86.5 & 1.64 & $<.0001$ \\
\hline $\mathrm{AME}_{\mathrm{N}}, \mathrm{MJ} \cdot \mathrm{kg}^{-1}$ & 8.80 & 9.36 & 0.07 & 0.075 \\
\hline \multicolumn{5}{|l|}{ Apparent ileal digestibility } \\
\hline dry matter & 61.3 & 64.4 & 1.80 & 0.267 \\
\hline crude protein & 81.7 & 82.8 & 0.89 & 0.396 \\
\hline Asp & 81.4 & 80.6 & 1.01 & 0.615 \\
\hline Thr & 78.9 & 79.1 & 1.01 & 0.906 \\
\hline Ser & 80.8 & 80.0 & 1.02 & 0.632 \\
\hline Glut & 89.3 & 88.2 & 0.69 & 0.322 \\
\hline Pro & 87.8 & 81.0 & 0.96 & 0.006 \\
\hline Cys & 80.9 & 83.0 & 1.52 & 0.367 \\
\hline Met. & 95.1 & 93.6 & 0.32 & 0.007 \\
\hline Gly & 78.7 & 79.5 & 1.27 & 0.704 \\
\hline Ala & 84.2 & 84.5 & 0.89 & 0.858 \\
\hline Val & 83.2 & 82.1 & 0.98 & 0.481 \\
\hline Iso & 84.9 & 84.0 & 0.85 & 0.507 \\
\hline Leu & 86.6 & 83.8 & 1.36 & 0.190 \\
\hline Tyr & 80.4 & 82.3 & 0.82 & 0.154 \\
\hline Phe & 85.4 & 84.6 & 0.75 & 0.474 \\
\hline His & 83.3 & 81.1 & 1.12 & 0.206 \\
\hline Lys & 88.0 & 87.7 & 0.74 & 0.774 \\
\hline $\operatorname{Arg}$ & 91.6 & 91.2 & 0.56 & 0.770 \\
\hline
\end{tabular}

SEM - standard error of mean, $\mathrm{AME}_{\mathrm{N}}$ - apparent metabolizable energy corrected to zero $\mathrm{N}$ balance

days 15 to 35 of the experiment, whereas in the whole experimental period (days $0-35$ ), the positive effect of extrusion was confirmed. Birds fed different lupin levels in extruded form were characterized by higher BWG than birds fed raw seeds. The interaction between extrusion and inclusion levels on BWG was not found in the study.

There was no effect of lupin inclusion as raw form on FI. Birds fed extruded lupin were characterized by quadratical decrease of FI from days 0 to 14 of the experiment $(P<0.037)$, whereas in the remaining periods, there was no statistically significant impact $(P>0.05)$. Extrusion did not change FI in the whole experimental period. Furthermore, no interaction was found between experimental factors.

The inclusion of narrow-leafed lupin seeds in raw and extruded forms into diet for broilers did not affect FCR in young birds (days 0-14), whereas in the remaining two studied periods (days 15-35 and $0-35$ ) the quadratical increase of FCR was 


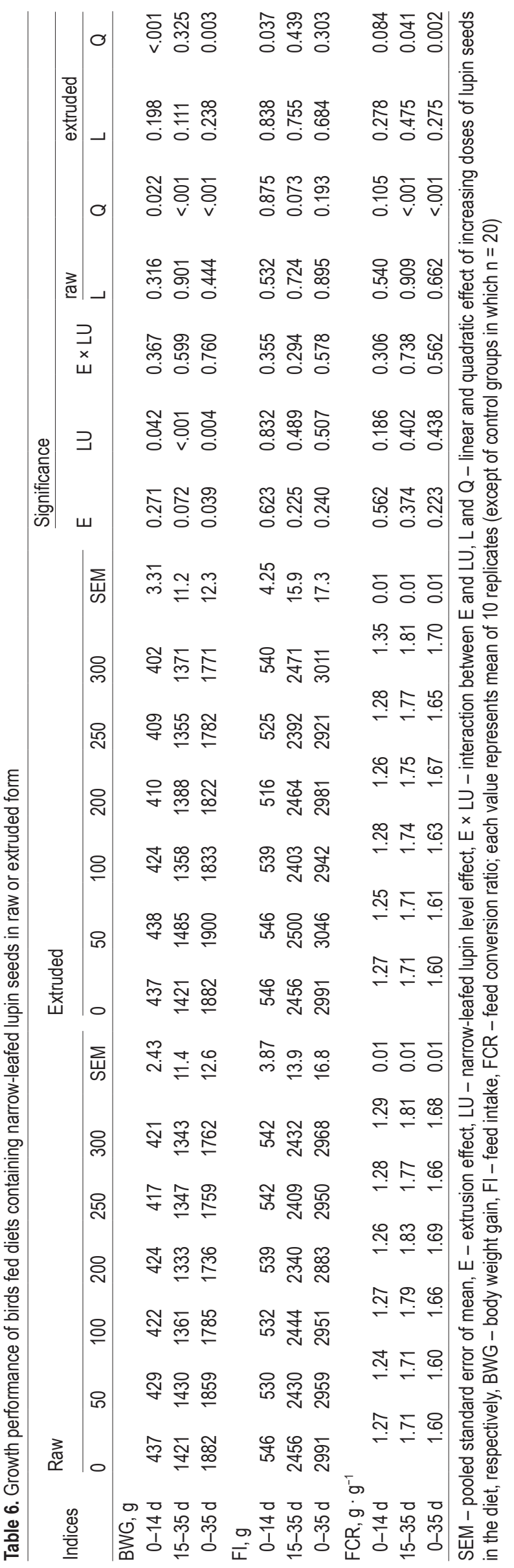

confirmed regardless lupin seed form. There was no effect of extrusion on FCR; moreover, an interaction between experimental factors was also not confirmed.

\section{Discussion}

During the past few years, modifications of lupin genotypes were focused on the improvement of agronomical traits, as well as on lowering the alkaloid content and increasing CP levels. The chemical composition of narrow-leafed lupin cv. Boruta used in this study was similar to older Polish cultivars of narrow-leafed lupin (Gdala and Buraczewska, 1996). Australian cultivars of lupin, as demonstrated by Nalle et al. (2011), are characterised by lower $\mathrm{CP}$ and similar EE concentration in comparison to our results. The narrow-leafed lupin cultivar used in this study was characterized by at least 10 -fold lower alkaloids content in comparison to the older narrow-leafed cultivars (Gdala and Buraczewska, 1996). The total oligosaccharide content determined in our study was higher than that reported by Gdala and Buraczewska (1996). According to previous research by Lahuta and Górecki (2011), the content of oligosaccharides in lupin seeds increases under drought conditions, so the observed differences could result from different environmental conditions during growth.

Compared to yellow lupin (Wasilewko and Buraczewska, 1999; Rutkowski et al., 2016), narrowleafed lupin seeds used in this study contained about 2 times more total alkaloids ( $44 \mathrm{mg} \cdot \mathrm{kg}^{-1}$ ) with the highest concentrations of lupamines and angustifoline. Although the contents of oligosaccharides were similar to those of narrow-leafed lupin and yellow seeds, the amount of phytate $\mathrm{P}$ was $7.0 \mathrm{~g} \cdot \mathrm{kg}^{-1}$ and

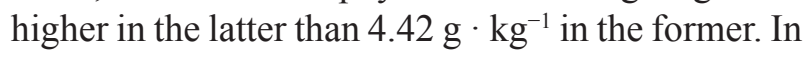
the earlier study of Rutkowski et al. (2016), the use of extrusion of yellow lupin seeds led to relatively minimal changes in nutrient composition, including AAs and antinutritional factors. Only the content of phytate $\mathrm{P}$ was reduced. In the present study, processing had no effect on chemical composition of narrow-leafed lupin seeds, except NDF content. Lower concentrations of this ingredient in extruded seeds had also been confirmed in our earlier study (Hejdysz et al., 2016a,b) and by other researchers (Diaz et al. 2006; Sobota et al., 2010). According to Sobota et al. (2010), low concentration of NDF in extruded seeds is caused by the decomposition of insoluble fractions into smaller molecules that are soluble in the NDF solution. These smaller soluble 
molecules were probably appearing in the nitrogen free extract. Changes in the ratio of soluble to insoluble fibre fractions in extruded seeds have been demonstrated in other studies (Martín-Cabrejas et al., 1999).

In some studies (Diaz et al., 2006), the beneficial effect of extrusion on digestibility coefficients of nutrients and reduction of the activity of thermolabile antinutritive substances was established. Additionally, in the study conducted by Rutkowski et al. (2016) and in the present one, the use of extrusion improved the crude fat digestibility and nitrogen retention in broiler chickens fed diet containing legume seeds. Interestingly, extrusion significantly improved $\mathrm{AME}_{\mathrm{N}}$ value of yellow lupin but in a lesser extent modulated the $\mathrm{AME}_{\mathrm{N}}$ value of narrow-leafed seeds (only tendency was confirmed). This effect may be the consequence of changes of the physicochemical structure of dietary fibre components and improved fat digestibility

In this study, extrusion did not affect the ileal digestibility of CP and most AAs in broilers fed narrowleafed lupin. These results are in contrast with those observed by Leontowicz et al. (2001) and in disagreement with the earlier study on yellow lupin by Rutkowski et al. (2016). Such discrepancies were probably due to no effect of extrusion on phytate $\mathrm{P}$ content in seeds, which was confirmed in the study on yellow lupin. The negative correlation between the concentration of phytate $\mathrm{P}$ and $\mathrm{CP}$ and AA digestibility was confirmed in a study on faba bean (Hejdysz et al., 2016a). Some authors have speculated that the mechanism of phytate action on CP and AAs can be explained by the presence of protein-phytate complexes in feedstuffs, the de novo formation of binary and ternary protein-phytate complexes in the digestive tract, phytate inhibition of proteolytic enzymes, and exacerbation of endogenous AA losses (Selle et al., 2006). It is difficult to explain why extrusion did not affect the phytic acid content in narrow-leafed lupin seeds, whereas lower phytate $P$ concentration was confirmed in the studies on faba bean, pea and yellow lupin (Hejdysz et al., 2016a,b; Rutkowski et al., 2016).

The positive experience of many authors concerning the effect of lupin extrusion on growth performance of poultry (Diaz et al., 2006; Lampart-Szczapa et al., 2007; Rutkowski et al., 2016) has been partly confirmed in this study. Better BWG of broilers fed diet with extruded lupin obtained in our study was probably caused by higher apparent total tract digestibility of crude fat and $\mathrm{AME}_{\mathrm{N}}$ (tendency). Therefore, the negative effect of increasing lupin antinutritional factors in the diet with extruded seeds on bird BWG was lower in comparison to broilers fed diets with increasing level of raw narrow-leafed lupin. Extrusion of narrow-leafed lupin seeds did not positively affect the FCR in chickens fed diets with increased levels of seeds, which could be explained by no effect of extrusion on the content of antinutritional factors in lupin seeds and particle size of extruded narrowleafed lupin seeds. According to Lv et al. (2015), particle size distribution of feed raw materials could affect nutrient utilization. The particle size of extruded narrow-leafed lupin after reground to pass through a $3.18 \mathrm{~mm}$ sieve was very fine. In more recent years, however, it has been thought that a large particle size aided by some structural components is beneficial to gizzard functions and gut development (Svihus et al., 2004; Choct, 2009). Therefore, it can be speculated that the one of factors responsible for the lack of positive impact of extrusion on broiler chicken performance is the particle size of extruded seeds.

Increasing level of narrow-leafed lupin seeds in diet depressed the growth performance in broiler chickens. Similar to the study presented by Steenfeldt et al. (2003), the substitution of soyabean meal and maize with $200 \mathrm{~g}$ narrow-leafed lupins per $\mathrm{kg}$ of broiler diets depressed BW and FCR. In comparison to our earlier study on yellow lupin (Rutkowski et al., 2016), broiler chickens tolerated 2 times lower concentration of narrow-leafed lupin than yellow lupin in the diet. Kaczmarek et al.(2014) showed a negative correlation between WEV and $\mathrm{AME}_{\mathrm{N}}$ of narrowleafed lupin seeds, as well as AA digestibility. Therefore, it could be speculated that the negative effect of narrow-leafed lupin could be connected to increased ileal digesta viscosity.

\section{Conclusions}

The extrusion of narrow-leafed lupin seed had a limited effect on its chemical composition. Extrusion influenced positively body weight gains of broiler chickens, whereas the effect of extrusion on feed intake and feed conversion ratio was not confirmed. An important observation was that the increasing levels of raw and extruded narrow-leafed lupin seeds quadratically worsened the body weight gain and feed conversion ratio during the experiment.

\section{Acknowledgements}

The presented study was the part of research project No. 505.037.07 'Improvement of native protein, feeds, their production, trade turnover and utilization in animal feed' granted by the Ministry of Agriculture and Rural Development of Poland. 


\section{References}

AOAC International, 2007. Official Methods of Analysis of AOAC International. $18^{\text {th }}$ Edition. ${ }^{\text {nd }}$ Revision. Gaithersburg, MD (USA)

Choct M., 2009. Managing gut health through nutrition. Br. Poult. Sci. 50, 9-15, https://doi.org/10.1080/00071660802538632

Diaz D., Morlacchini M., Masoero F., Moschini M., Fusconi G., Piva G., 2006. Pea seeds (Pisum sativum), faba beans (Vicia faba var. minor) and lupin seeds (Lupinus albus var. multitalia) as protein sources in broiler diets: effect of extrusion on growth performance. Ital. J. Anim. Sci. 5, 43-53, https://doi.org/10.4081/ ijas.2006.43

Farrell D.J., Perez-Maldonado R.A., Mannion P.F., 1999. Optimum inclusion of field peas, faba beans, chick peas and sweet lupins in poultry diets. II. Broiler experiments. Br. Poult. Sci. 40, 674-680, https://doi.org/10.1080/00071669987070

Gdala J., Buraczewska L., 1996. Chemical composition and carbohydrate content of seeds from several lupin species. J. Anim. Feed Sci. 5, 403-416, https://doi.org/10.22358/ jafs/69618/1996

Haug W., Lantzsch H.-J., 1983. Sensitive method for the rapid determination of phytate in cereals and cereal products. J. Sci. Food Agric. 34, 1423-1426, https://doi.org/10.1002/ jsfa.2740341217

Hejdysz M., Kaczmarek S.A., Rutkowski A., 2016b. Effect of extrusion on the nutritional value of peas for broiler chickens. Arch. Anim. Nutr. 70, 364-377, https://doi.org/10.1080/174503 9X.2016.1206736

Hejdysz M., Kaczmarek S.A., Rutkowski A., 2016a. Extrusion cooking improves the metabolisable energy of faba beens and the amino acid digestibility in broilers. Anim. Feed Sci. Technol. 212, 100-111, https://doi.org/10.1016/j.anifeedsci.2015.12.008

Hejdysz M., Kaczmarek S.A., Rutkowski A., 2015. Factors affecting the nutritional value of pea (Pisum sativum) for broilers. J. Anim. Feed Sci. 24, 252-259, https://doi.org/10.22358/ jafs/65631/2015

Hill F., Anderson D.L., 1958. Comparison of metabolizable energy and productive energy determination with growing chicks. J. Nutr. $64,587-603$

Jamroz D., Kubizna J., 2008. Harmful substances in legume seeds their negative and beneficial properties. Polish J. Vet. Sci. 11, 389-404

Kaczmarek S.A., Kasprowicz-Potocka M., Hejdysz M., Mikuła R., Rutkowski A., 2014. The nutritional value of narrow-leafed lupin (Lupinus angustifolius) for broilers. J. Anim. Feed Sci. 23, 160-166, https://doi.org/10.22358/jafs/65705/2014

Lahuta L.B., Górecki R.J., 2011. Raffinose in seedlings of winter vetch (Vicia villosa Roth.) under osmotic stress and followed by recovery. Acta Physiol. Plant. 33, 725-733, https://doi. org/10.1007/s11738-010-0597-4

Lampart-Szczapa E., Kossakowska J., Nogala-Kałucka M., Malinowska M., Siger A., 2007. Phenolic compounds of extruded lupin preparations (in Polish). Zesz. Probl. Post. Nauk Rol. 522, 393-397

Lampart-Szczapa E., Łoza A., 2007. Functional components of lupin seeds - the advantages and potential disadvantages (in Polish). Zesz. Probl. Post. Nauk Rol. 522, 387-392

Laudadio V., Tufarelli V., 2011b. Dehulled-micronised lupin (Lupinus albus L. Cv. Multitalia) as the main protein source for broilers: influence on growth performance, carcass traits and meat fatty acid composition. J. Sci. Food Agric. 91, 2081-2087, https://doi.org/10.1002/jsfa.4426
Laudadio V., Tufarelli V., 2011a. Influence of substituting dietary soybean meal for dehulled-micronized lupin (Lupinus albus cv. Multitalia) on early phase laying hens production and egg quality. Livest. Sci. 140, 184-188, https://doi.org/10.1016/j. livsci.2011.03.029

Leontowicz H., Leontowicz M., Kostyra H., Kulasek G., Gralak M.A., Krzemiński R., Podgurniak M., 2001. Effects of raw or extruded legume seeds on some functional and morphological gut parameters in rats. J. Anim. Feed Sci. 10, 169-183, https:// doi.org/10.22358/jafs/67957/2001

Lv M., Yan L., Wang Z., An S., Wu M., Lv Z., 2015. Effects of feed form and feed particle size on growth performance, carcass characteristics and digestive tract development of broilers. Anim. Nutr. 1, 252-256, https://doi.org/10.1016/j.aninu.2015.06.001

Martín-Cabrejas M.A., Jaime L., Karanja C., Downie A.J., Parker M.L., Lopez-Andreu F.J., Maina G., Esteban R.M., Smith A.C., Waldron K.W., 1999. Modifications to physicochemical and nutritional properties of hard-to-cook beans (Phaseolus vulgaris L.) by extrusion cooking. J. Agric. Food Chem. 47, 1174-1182, https://doi.org/10.1021/jf980850m

Myers W.D., Ludden P.A., Nayigihugu V., Hess B.W., 2004. Technical note: A procedure for the preparation and quantitative analysis of samples for titanium dioxide. J. Anim. Sci. 82, 179-183, https://doi.org/10.2527/2004.821179x

Nalle C.L., Ravindran V., Ravindran G., 2011. Nutritional value of narrow-leafed lupin (Lupinus angustifolius) for broiler. $\mathrm{Br}$. Poult. Sci. 52, 775-781, https://doi.org/10.1080/00071668. 2011.639343

Rubio L.A., Brenes A., Centeno C., 2003. Effects of feeding growing broiler chickens with practical diets containing lupin (Lupinus angustifolius) seed meal. Br. Poult. Sci. 44, 391-397, https:// doi.org/10.1080/0007166031000085553

Rutkowski A., Kaczmarek S.A., Hejdysz M., Adamski M., Nowaczewski S., Jamroz D., 2017. The effect of addition of yellow lupin seeds (Lupinus luteus L.) to laying hen diets on performance and egg quality parameters. J. Anim. Feed Sci. 2017, 26, 247-256, https://doi.org/10.22358/jafs/76322/2017

Rutkowski A., Kaczmarek S.A., Hejdysz M., Jamroz D., 2016. Effect of extrusion on nutrients digestibility, metabolizable energy and nutritional value of yellow lupine seeds for broiler chickens. Ann. Anim. Sci. 16, 1059-1072, https://doi.org/10.1515/ aoas-2016-0025

Rutkowski A., Kaczmarek S.A., Hejdysz M., Nowaczewski S., Jamroz D., 2015. Concentrates made from legume seeds ( $L u$ pinus angustifolius, Lupinus lutens and Pisum sativum) and rapeseed meal as protein source in laying hen diets. Ann. Anim. Sci. 15, 129-142, https://doi.org/10.2478/aoas-20140061

Selle P.H., Ravindran V., Bryden W.L., Scott T., 2006. Influence of dietary phytate and exogenous phytase on amino acid digestibility in poultry. A review. J. Poult. Sci. 43, 89-103, https:// doi.org/10.2141/jpsa.43.89

Short F.J., Gorton P., Wiseman J., Boorman K.N., 1996. Determination of titanium dioxide added as an inert marker in chicken digestability studies. Anim. Feed Sci. Technol. 59, 215-221, https://doi.org/10.1016/0377-8401(95)00916-7

Smulikowska S., Konieczka P., Czerwinski J., Mieczkowska A., Jankowiak J., 2013. Feeding broiler chickens with practical diets containing lupin seeds ( $L$. angustifolius or $L$. luteus): effects of incorporation level and mannanase supplementation on growth performance, digesta viscosity, microbial fermentation and gut morphology. J. Anim. Feed Sci. 23, 64-72, https://doi.org/10.22358/jafs/65718/2014 
Smulikowska S., Pastuszewska B., Mieczkowska A., Lechowski R., 1999. Effect of gramine - indole alkaloid of yellow lupin on performance and some physiological parameters in broiler chicken. In: Proceedings of the $12^{\text {th }}$ European Symposium on Poultry Nutrition. Veldhoven (the Netherlands), pp. 313-315

Smulikowska S., Rutkowski A. (Editors), 2005. Recommended Allowances and Nutritive Value of Feedstuffs. Poultry Feeding Standards (in Polish). $4^{\text {th }}$ Edition. The Kielanowski Institute of Animal Physiology and Nutrition, PAS, Jabłonna (Poland)

Sobota A., Sykut-Domańska E., Rzedzicki Z., 2010. Effect of extrusioncooking process on the chemical composition of corn-wheat extrudates, with particular emphasis on dietary fibre fractions. Pol. J. Food Nutr. Sci. 60, 251-259

Steenfeldt S., González E., Bach Knudsen K.E., 2003. Effects of inclusion with blue lupins (Lupinus angustifolius) in broiler diets and enzyme supplementation on production performance, digestibility and dietary AME content. Anim. Feed Sci. Technol. 110, 185-200, https://doi.org/10.1016/S0377-8401(03)00218-9
Svihus B., Juvik E., Hetland H., Krogdahl Å., 2004. Causes for improvement in nutritive value of broiler chicken diets with whole wheat instead of ground wheat. Br. Poult. Sci. 45, 55-60, https://doi.org/10.1080/00071660410001668860

Wasilewko J., Buraczewska L., 1999. Chemical composition including content of amino acids, minerals and alkaloids in seeds of three lupin species cuiltivated in Poland. J. Anim. Feed Sci. 8, 1-12, https://doi.org/10.22358/jafs/68803/1999

World's Poultry Science Association, 1989. European Table of Energy Values for Poultry Feedstuffs. $3^{\text {rd }}$ Edition. Subcommittee Energy of the Working Group No 2 (Nutrition) of the European Federation of Branches of the World's Poultry Science Association. Beekbergen (The Netherlands)

Zalewski K., Lahuta L.B., Horbowicz M., 2001. The effect of soil drought on the composition of carbohydrates in yellow lupin seeds and triticale kernels. Acta Physiol. Plant. 23, 73-78, https://doi.org/10.1007/s11738-001-0025-x 